S. Ivanovski*, H.R. Haase, and P.M. Bartold

Department of Dentistry, University of Queensland, Turbot Street, Brisbane, Queensland, 4000, Australia;

*corresponding author, s302219@student.uq.edu.au

J Dent Res 80(7): 1665-1671, 2001

\section{Expression of Bone Matrix Protein mRNAs by Primary and Cloned Cultures of the Regenerative Phenotype of Human Periodontal Fibroblasts}

\section{INTRODUCTION}

A primary goal of periodontal therapy is regeneration of the tissues that have been destroyed by periodontitis. Guided tissue regeneration is a surgical technique that utilizes barrier membranes to exclude undesirable cells, such as epithelial and gingival connective tissue cells, from the periodontal defect, thus allowing for repopulation by cells capable of regenerating the desired structures (i.e., cementum, bone, periodontal ligament). However, because predictable regeneration is not always achieved by this and other regenerative techniques (Laurell et al., 1998), the cellular and molecular events occurring during this type of wound healing require ongoing investigations. The heterogenous nature of the fibroblasts that populate the periodontium, together with the complex interactions which occur between hard and soft tissues during periodontal wound healing, is a poorly understood concept which is of paramount importance in periodontal regeneration.

The aims of the present study were to establish and characterize primary fibroblast cultures, and single-cell-derived clones, obtained from the regenerating tissues and to compare them with gingival and periodontal ligament fibroblast cultures obtained from adjacent tissues in the same patient. Since restoration of cementum and bone lost to periodontitis is an essential requirement of periodontal regeneration, we have hypothesized that cells of a regenerating phenotype should express mRNA for proteins associated with hard-tissue formation. Hence, we assessed the expression of mRNA for osteopontin, osteocalcin, bone sialoprotein, alkaline phosphatase, and bone morphogenetic proteins-2 and -4 (BMP-2 and BMP-4), because these proteins have unique distributions within the periodontium, are secreted at different stages of osteogenic cell differentiation, and/or play important roles in cementogenesis and osteogenesis (Bronckers et al., 1994; MacNeil et al., 1995; Boskey, 1996; Thesleff and Nieminen, 1996; Lee, 1997). The properties exhibited by these proteins make them potentially useful as markers of osteoprogenitor/cementoprogenitor cells residing within the periodontium.

\section{MATERIALS \& METHODS}

\section{Surgical Procedure}

Following attainment of institutional ethics approval and informed consent from three subjects, buccal flaps were raised around periodontal defects associated with non-carious teeth destined for extraction in preparation for immediate denture construction. Granulation tissue was removed from the defect, and the tooth surface was thoroughly debrided prior to placement of an expanded polytetrafluoroethylene membrane (W.L. Gore \& Associates, Flagstaff, AZ, USA). Following a six-week healing period, the membrane was removed, the regenerated tissue was excised, a biopsy of the buccal gingiva was obtained, and the tooth was extracted.
Received May 15, 2000; Last revision March 8, 2001; Accepted March 26, 2001

A supplemental appendix to this article is published electronically only at http://www.dentalresearch.org. 


\section{Cell Isolation and Culture}

Periodontal fibroblasts were isolated and cultured as reported previously (Somerman et al., 1988). Briefly, the periodontal ligament, gingival, and regenerating tissues were cut into small pieces and cultured in Dulbecco's modified Eagle's medium (DMEM) with $10 \%$ fetal calf serum (FCS), 50 units/mL penicillin, and $50 \mu \mathrm{g} / \mathrm{mL}$ streptomycin. Cells between the 4 th and 5 th transfers in culture were used.

\section{Transfection and Establishment of Clones}

The fibroblast cultures were transfected by use of the putative transforming genes E6 and E7 from the human papilloma virus type 16 prototype, which were contained in the retrovirus vector, $\mathrm{pLXSN}$ (Shiga et al., 1997). The amphotropic virus LXSN16E6E7 was produced by the NIH 3T3-derived mouse fibroblast packaging line PA317 and used to infect the three primary fibroblast cell lines, which were subsequently selected in standard culture medium containing G418 $(1 \mathrm{mg} / \mathrm{mL})$. We obtained clones of the transfected cells by seeding them into 24-well plates using a limiting dilution of 0.3-0.4 cells/well. Clone growth was microscopically assessed on a daily basis to ensure that each clone had originated from a single cell. Following the establishment of the clones, 9 clonal populations (representing 3 from each cell type) derived from one patient were randomly selected for analysis.

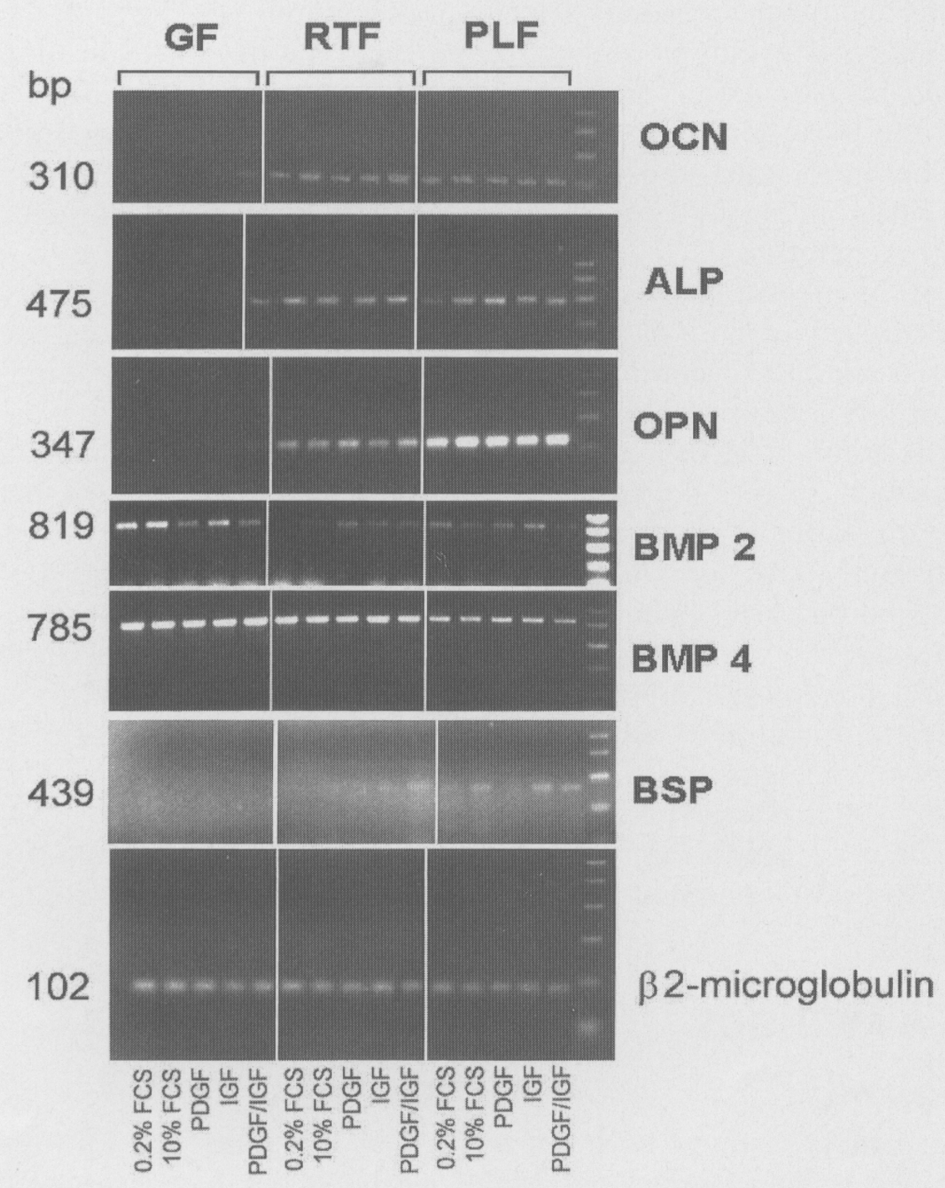

Figure 1. Representative agarose gel showing RT-PCR products from one patient. The expression of osteopontin, osteocalcin, and bone sialoprotein in periodontal ligament (PLF) and regenerating tissue fibroblasts (RTF) is up-regulated compared with gingival fibroblasts (GF). $\mathrm{OCN}=$ osteocalcin; $\mathrm{ALP}=$ alkaline phosphatase; $\mathrm{OPN}=$ osteopontin; $\mathrm{BSP}=$ bone sialoprotein; $\mathrm{BMP}-2$ = bone morphogenetic protein-2; BMP-4 = bone morphogenetic protein- 4 .

\section{Growth Factor Stimulation}

Upon reaching $80 \%$ confluence, the cells were exposed to culture media containing various growth factors, including: $0.2 \% \mathrm{FCS}$, $10 \% \mathrm{FCS}, 10 \mathrm{ng} / \mathrm{mL}$ PDGF-BB in $0.2 \% \mathrm{FCS}, 100 \mathrm{ng} / \mathrm{mL}$ IGF- 1 in $0.2 \% \mathrm{FCS}$, and a combination of $10 \mathrm{ng} / \mathrm{mL}$ PDGF-BB and 100 $\mathrm{ng} / \mathrm{mL} \mathrm{IGF-1} \mathrm{in} 0.2 \% \mathrm{FCS}$. These conditions were based on previous studies which have shown them to stimulate a variety of periodontal cells with regard to cell proliferation and matrix protein synthesis (Haase et al., 1998).

\section{RT-PCR Analysis}

Total cellular RNA was isolated from the three populations by means of a Rneasy Mini Kit (QIAGEN Pty Ltd, Victoria, Australia) as described previously (Haase et al., 1998). cDNA was synthesized from $1 \mu \mathrm{g}$ of total RNA which was primed with Oligo $\mathrm{dT}$. The final $20-\mu \mathrm{L}$ reaction mixture, containing $1 \times$ reverse transcriptase buffer (Promega, Madison, WI, USA), dCTP, dGTP, dATP, and dTTP each at $500 \mu \mathrm{M}, 20 \mathrm{U}$ of RNAse inhibitor, and $100 \mathrm{U}$ of $\mathrm{M}$-MLV enzyme, was incubated at $37^{\circ} \mathrm{C}$ for $1 \mathrm{hr}$ followed by $99^{\circ} \mathrm{C}$ for $5 \mathrm{~min}$.

Aliquots of $2 \mu \mathrm{L}$ (for $\beta$-2-microglobulin, alkaline phosphatase, bone morphogenetic protein-2, and bone morphogenetic protein-4) and $4 \mu \mathrm{L}$ (for osteopontin, osteocalcin, and bone sialoprotein) of the total cDNA were amplified with $10 \mathrm{pmol}$ of $5^{\prime}$ and $3^{\prime}$ primer, $1 \mathrm{x}$ PCR buffer (Promega), dCTP, dGTP, dATP, and dTTP each at $0.4 \mathrm{mM}, 1.5$

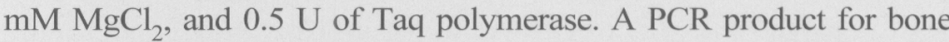
sialoprotein was obtained only by increasing the primer and $\mathrm{MgCl}_{2}$ concentrations to $50 \mathrm{pmol}$ and $3 \mathrm{mM}$, respectively. A minimum of 3 PCR reactions was carried out for each cDNA sample. Amplifications were performed in a thermal cycler (MJ Research, Watertown, MA, USA). Twenty-five cycles were used for $\beta 2$-microglobulin and alkaline phosphatase, 30 cycles for BMP-2 and BMP-4, and 35 for osteopontin, osteocalcin, and bone sialoprotein. The primer sequence for bone sialoprotein (F:GCCTGTGCTTTCTCAATG and R:TTCCTTCCTCTTCCTCCTC) was designed by means of the GCG program "Prime" (Program Manual for the Wisconsin Package, Version 8, September 1994, Genetics Computer Group, Madison, WI, USA), whereas previously published sequences were used for osteopontin, osteocalcin, alkaline phosphatase (Rickard et al., 1996), BMP-2, and BMP-4 ( $\mathrm{Li}$ et al., 1998). Reaction products were analyzed and visualized by electrophoresis of $10-\mu \mathrm{L}$ samples in 1.5 $2 \%$ agarose gels containing $0.5 \mu \mathrm{g} / \mathrm{mL}$ ethidium bromide. The identity of the PCR products was confirmed by sequencing. We quantified the DNA bands by measuring their density using image analysis (NIH Image Analysis version 1.57, Bethesda, MD, USA). Statistical analysis of the results was carried out by one-way ANOVA.

\section{RESULTS}

\section{Primary Cultures}

A representative agarose gel from one patient is shown in Fig. 1. The RT-PCR analyses (Fig. 2) showed that there were significantly higher levels of osteocalcin and osteopontin mRNA expression in the regenerating tissue fibroblasts and periodontal ligament fibroblasts compared with the gingival fibroblasts $(p<0.01)$. Furthermore, bone sialoprotein mRNA expression was noted only in the periodontal ligament fibroblasts and regenerating tissue fibroblasts. There were no significant differences noted between periodontal ligament fibroblasts and regenerating tissue fibroblasts with respect to the mRNA expression of any of the proteins. Furthermore, the 
Table. RT-PCR Product Band Intensities (relative to $\beta-2$ microglobulin) of Mineralized-tissue-associated mRNAs Derived from Primary Cultures and Clones at the Baseline (0.02\% FCS) level

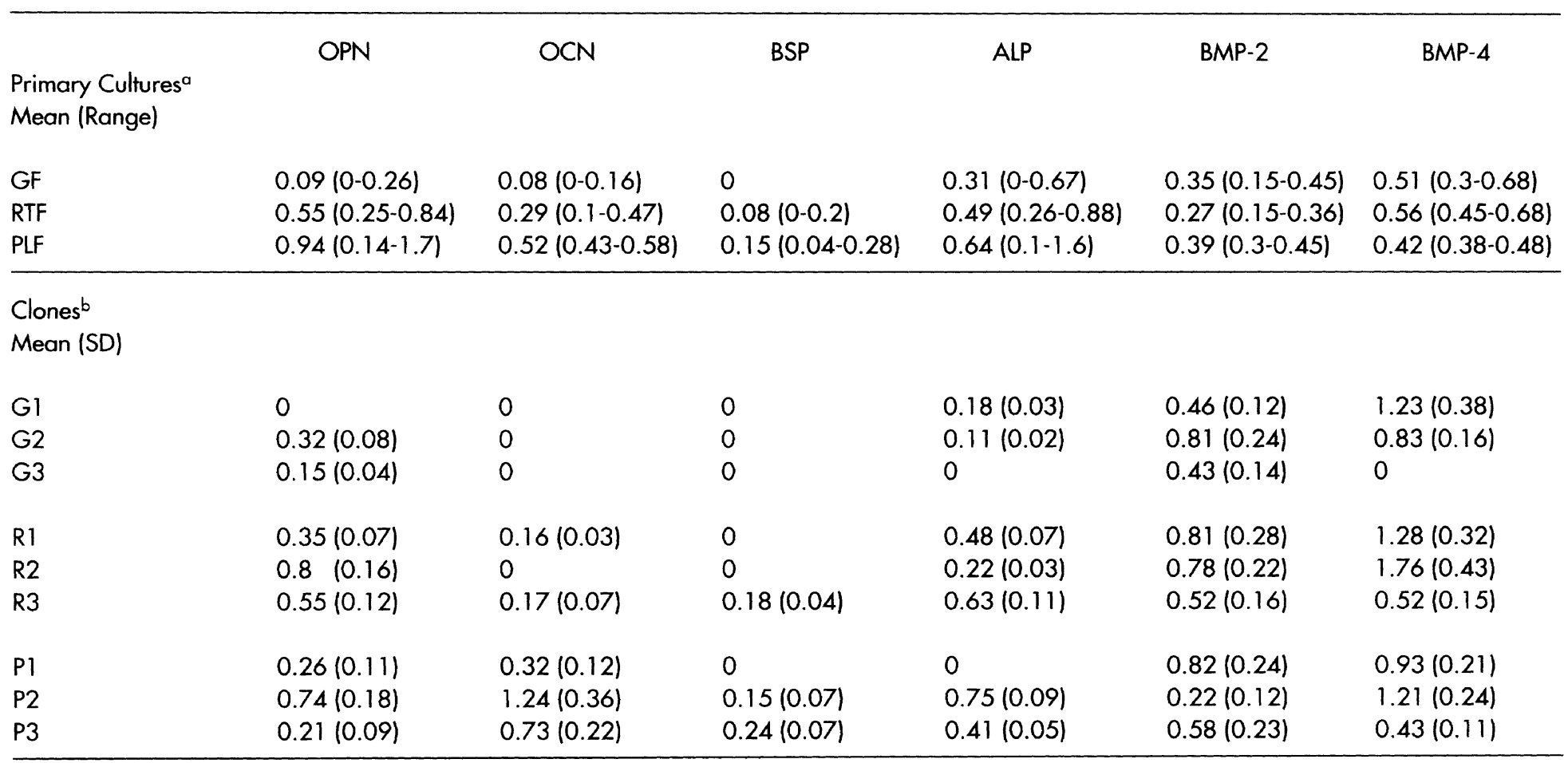

a The primary culture data are presented as the mean of the three patients studied, and the range is included to show the level of inter-patient heterogeneity that was encountered.

b The data derived from the cloned cultures are presented as the mean and standard deviation (SD) of triplicate samples.

three cell populations did not express any significant differences in the BMP-2, BMP-4, and alkaline phosphatase mRNA expression. PDGF and IGF-I did not have a significant effect on the mRNA expression of any of the molecules studied.

There was considerable heterogeneity within each set of three regenerating tissue, periodontal ligament, and gingival fibroblast populations with regard to the mRNA expression of all of the molecules (Table). For example, only one of the three gingival fibroblast populations expressed osteocalcin mRNA, whereas two periodontal ligament fibroblast populations expressed high levels of alkaline phosphatase mRNA, while the expression level in the remaining population was low.

\section{Clones}

Single-cell-derived clones were successfully established from the transfected primary cultures. Initial assessment indicated that the general growth rates and protein synthesis were not different from those of the parent cultures (results not shown). The baseline $(0.2 \%$ FCS-treated) mineralized tissue marker mRNA expression by the clones, as measured by the RT-PCR product band intensities (relative to $\beta$-2microglobulin), is presented in the Table. The mRNA expression in the 9 clonal populations was consistent with the findings in the primary cell populations. There was considerable heterogeneity with respect to the mRNA expression of the majority of the proteins studied. Generally, there were greater incidence and intensity of bone sialoprotein, osteocalcin, osteopontin, and alkaline phosphatase mRNA expression in the regenerating tissue fibroblasts and periodontal ligament fibroblasts compared with those of the gingival fibroblasts. Of particular interest was the ubiquitous and strong expression of mRNA for all the hard-tissue-associated proteins that was observed in several clones, namely, R3, P2, and P3.

The PDGF and IGF effect on mRNA expression by two representative clones from each cell population is illustrated in Fig. 3. The PDGF and IGF effect on mineralized tissueassociated genes was more pronounced in certain clonal populations. For example, osteopontin, osteocalcin, alkaline phosphatase, and BMP-2 mRNAs were all up-regulated by PDGF and/or IGF in the R1 clones. There was no correlation between mineralized tissue marker expression and cellular proliferation, as measured by a ${ }^{3} \mathrm{H}$-thymidine incorporation assay, in response to growth factor exposure. Indeed, PDGF and IGF-I had a mitogenic effect on the clonal populations (see Fig. in electronic Appendix), similar to that observed in primary cultures of periodontal cells (Haase et al., 1998).

\section{DISCUSSION}

This study has attempted to characterize cells isolated from regenerating periodontal defects. The findings, which show that regenerating tissue fibroblasts and periodontal ligament fibroblasts express higher levels of mRNA for mineralizedtissue-associated proteins compared with gingival fibroblasts, complement earlier immunohistochemical studies showing that these proteins accumulate in regenerating periodontal defects (Amar et al., 1997; Ivanovski et al., 2000). 

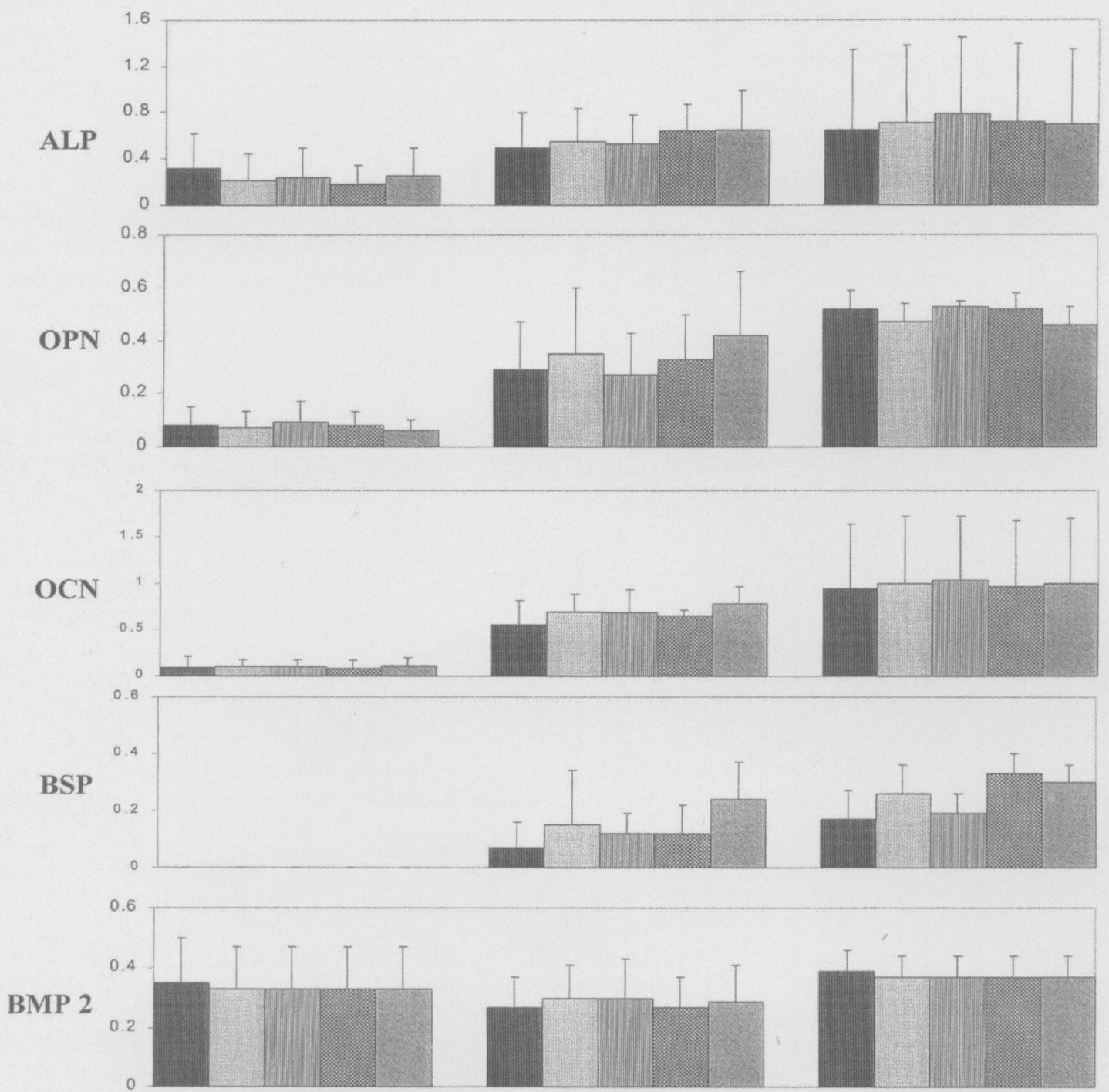

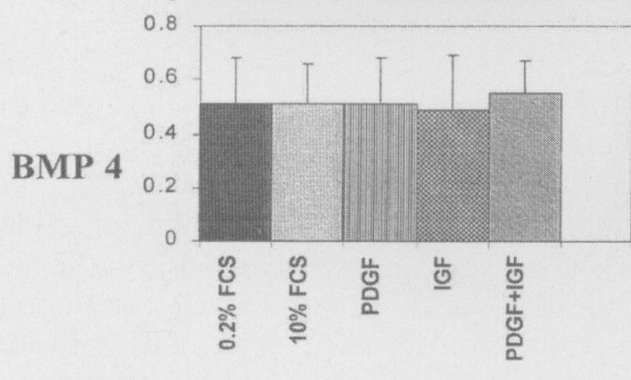

GF

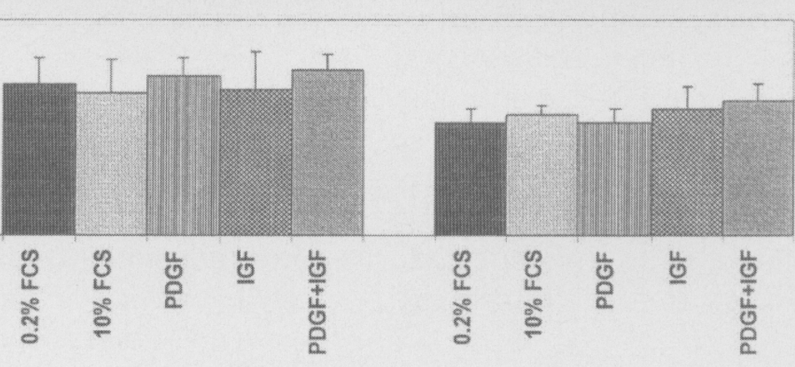

PLF
Figure 2. Graphical analysis of RT-PCR product band intensities relative to $\beta$-microglobulin, illustrating significantly greater $(p<0.01)$ expression of osteopontin, osteocalcin, and bone sialoprotein in periodontal ligament (PLF) and regenerating tissue fibroblasts (RTF) compared with gingival fibroblasts (GF). PDGF and IGF1 do not significantly alter the mRNA expression of the mineralized tissue proteins. Abbreviations as in Fig. 1.

al., 1994; MacNeil et al., 1995; Lekic et al., 1996). Furthermore, the mRNAs for these proteins are expressed in a specific temporal and spatial manner during cementogenesis (MacNeil et al., 1995; D'Errico et al., 1997). Therefore, the strong mRNA expression noted for osteopontin, osteocalcin, and bone sialoprotein indicates the potential for hard-tissue formation by a subpopulation of cells residing within the periodontal ligament and regenerating defect. The expression of these genes may be used to identify cells of the osteoblastic/cementoblastic lineage within these populations.

Bone sialoprotein, in particular, is an excellent marker for mineralizedtissue-specific cells because of its role as initiator of biomineralization (Hunter and Goldberg, 1993). Furthermore, bone sialoprotein is localized in cementum and bone but not within the periodontal ligament (MacNeil et al., 1995; D'Errico et al., 1997). Since some undifferentiated fibroblastic pre-osteoblasts have been shown to express bone sialoprotein mRNA (Liu et al., 1994), it may be speculated that the source of bone sialoprotein mRNA noted within the periodontal ligament fibroblast populations could be cementoblast and/or osteoblast precursors.

Although earlier studies have reported increased activity of alkaline phosphatase in periodontal ligament fibroblast cultures

The increased osteopontin, osteocalcin, and bone sialoprotein mRNA expression by the regenerating tissue fibroblasts and periodontal ligament fibroblasts is significant, because these proteins are secreted at different stages during osteogenic cell differentiation (Boskey, 1996) and have unique distributions within the periodontium (Bronckers et
(Somerman et al., 1988), our findings of no significant difference in the level of alkaline phosphatase mRNA expression among the regenerating tissue, periodontal ligament, and gingival fibroblasts are consistent with recent reports of alkaline phosphatase activity in gingival fibroblasts (Carnes et al., 1997). 

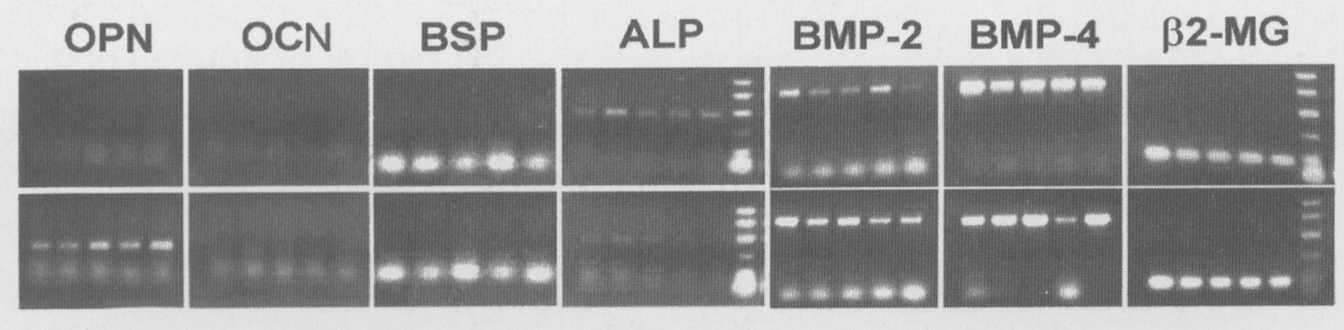

\section{G1 \\ G2}
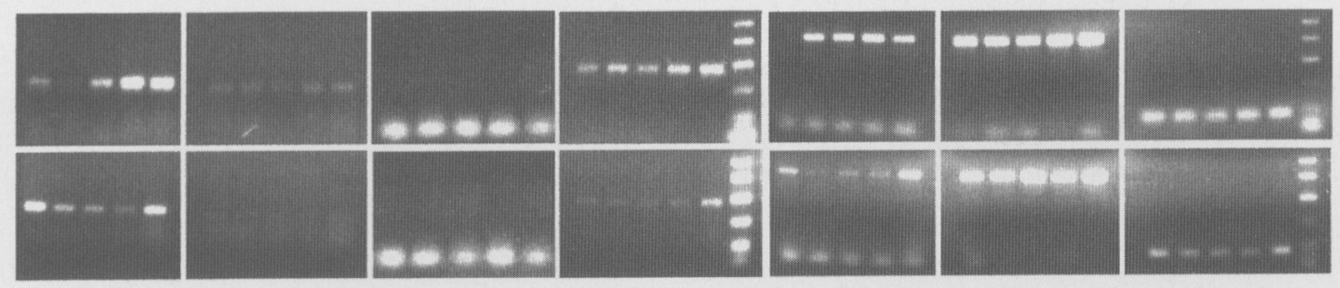

R1
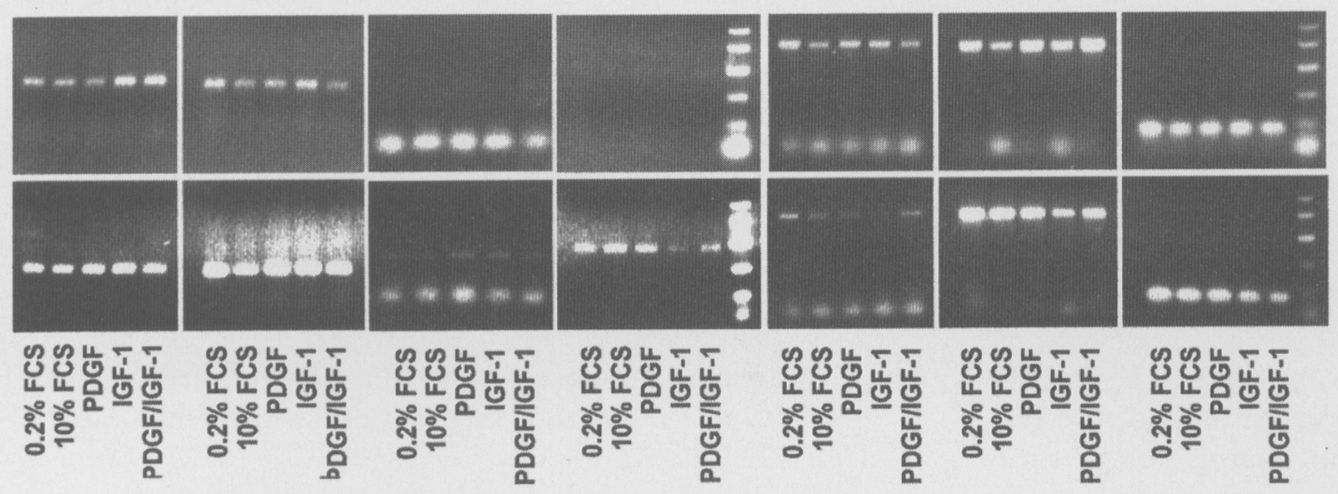

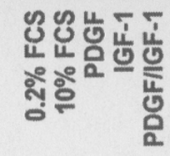

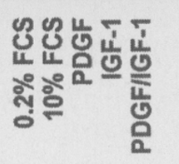

information on the expression of osteoblast-associated genes by cultured human periodontal cells necessitates the pursuit of this method of analysis.

In periodontal cells, PDGF and/or IGF-1 have been shown to affect extracellular matrix synthesis via the up-regulation of collagen (Matsuda et al. 1992) and proteoglycan (Haase et al., 1998) synthesis, as well as BMP-2 and BMP-4 mRNA (Li et al., 1998). In this study, PDGF and IGF-I did not significantly affect the mRNA expression of any of the proteins studied. The findings of this study are supported by the reported lack of PDGF and/or IGF-1 effect on osteocalcin, osteopontin, and/or alkaline phosphatase mRNA expression in osteoblast and their precursors (Canalis and Lian, 1988; Tanaka and Liang, 1995; Thomas et al., 1999). However, IGF-1 and PDGF have been reported both to stimulate and to inhibit various mineralized tissue molecules in a variety of in

BMP-2 and BMP-4 play important roles in tooth morphogenesis (Thesleff and Nieminen, 1996). During development, the translation of these proteins is highly regulated in both a spatial and temporal sense (Lee et al., 1997). Hence, although there were no differences in mRNA expression for BMP-2 and BMP-4 among the regenerating tissue, periodontal ligament, and gingival fibroblasts, this may not correlate with the protein expression by these cells.

The extensive heterogeneous expression of mineralized tissue protein mRNA by the three cell populations is not surprising, since the cells inhabiting the periodontium are noted for their considerable heterogeneity (Hassell and Stanek, 1983; Giannopoulou and Ciamasoni, 1996; Kuru et al., 1998). Osteoblast precursors and mature osteoblasts are also considerably heterogeneous in terms of mRNA expression for alkaline phosphatase, osteocalcin, osteopontin, and bone sialoprotein (Liu et al., 1997).

The limitations of quantifiable data obtained by the use of the highly sensitive RT-PCR method must be noted. Indeed, Northern blotting would have provided more directly quantifiable results. However, as has been the case in previous studies (Nohutcu et al., 1997; Parkar et al., 1999), we were unable to use Northern blotting successfully to detect osteoblast-associated genes in human periodontal cells. Although this limits the quantitative conclusions drawn from our results, the scarcity of vitro models (Tanaka and Liang, 1995; Langdahl et al., 1998; Strayhorn et al., 1999). Hence, it appears that the effects of PDGF and IGF-1 on osteoblast-associated genes are dependent on a variety of factors, including growth factor concentrations and duration of application, source and phenotype of the cells under investigation, as well as the stage of cell differentiation.

The successful transfection and subsequent cloning of human periodontal cells are of particular interest, as is the apparent ability of the clones to retain the characteristics of the parent cultures. The establishment of cloned human cells from regenerating periodontal tissues now provides us with a stable in vitro system for the study of various phenotypes (e.g., fibroblast, cementoblast, and osteoblast precursors) involved in regeneration. The study of clonal populations may be used to overcome the difficulties associated with the extensive heterogeneity of primary cultures of periodontal cells. Indeed, the influence of PDGF and IGF-1 on osteoblast-associated gene expression was more pronounced in certain clones compared with the primary cultures, and this finding can be attributed to the use of isolated phenotypes.

In conclusion, this study has shown that human regenerating tissue fibroblasts have phenotypes consistent with an ability to produce mineralized tissues. The increased level of mineralized tissue mRNA in periodontal ligament 
fibroblasts and regenerating tissue fibroblasts compared with gingival fibroblasts supports the concept that cells originating from within the periodontal ligament (including those from cementum and bone) have the ability to regenerate lost periodontal attachment. Furthermore, these findings reinforce the necessity for investigating means to facilitate periodontal regeneration through the promotion of selective repopulation of the defect by cells with a regenerative phenotype.

\section{ACKNOWLEDGMENTS}

The transfection of the three primary cell lines was carried out at the Lions Human Immunology Laboratories, Brisbane, Queensland, Australia. This study was supported by the Australian National Health and Medical Research Council.

\section{REFERENCES}

Amar S, Chung KM, Nam SH, Karatzas S, Myokai F, Van Dyke TE (1997). Markers of bone and cementum formation accumulate in tissues regenerated in periodontal defects treated with expanded polytetrafluoroethylene membranes. $J$ Periodontal Res 32:148-158.

Boskey AL (1996). Matrix proteins and mineralization: an overview. Connect Tissue Res 35:357-363.

Bronckers ALJJ, Farach-Carson MC, van Waeren E, Butler WT (1994). Immunolocalization of osteopontin, osteocalcin, and dentin sialoprotein during dental root formation and early cementogenesis in the rat. $J$ Bone Miner Res 9:833-841.

Canalis E, Lian JB (1988). Effects of bone associated growth factors on DNA, collagen and osteocalcin synthesis in cultured fetal rat calvariae. Bone 9:243-246.

Carnes DL, Maeder CL, Graves DT (1997). Cells with osteoblastic phenotypes can be explanted from human gingiva and periodontal ligament. J Periodontol 68:701707.

D'Errico JA, MacNeil RL, Takata T, Berry J, Strayhorn C, Somerman MJ (1997). Expression of bone associated markers by tooth root lining cells, in situ and in vitro. Bone 20:117-126.

Giannopoulou C, Ciamasoni G (1996). Functional characteristics of gingival and periodontal ligament fibroblasts. J Dent Res 75:895-902.

Haase HR, Clarkson RW, Waters MJ, Bartold PM (1998). Growth factor modulation of mitogenic responses and proteoglycan synthesis by human periodontal fibroblasts. J Cell Physiol 174:353-361.

Hassell TM, Stanek EJ (1983). Evidence that the healthy human gingiva contains functionally heterogeneous fibroblast subpopulations. Arch Oral Biol 28:617-625.

Hunter GK, Goldberg HA (1993). Nucleation of hydroxyapatite by bone sialoprotein. Biochem 90:8562-8565.

Ivanovski S, Li H, Daly T, Bartold PM (2000). An immunohistochemical study of matrix molecules associated with barrier membrane mediated periodontal wound healing. J Periodont Res 35:115-126.

Kuru L, Parker MH, Griffiths GS, Newman HN, Olsen I (1998). Flow cytometry analysis of gingival and periodontal ligament cells. J Dent Res 77:555-564.

Langdahl BL, Kassem M, Moller MK, Eriksen EF (1998). The effects of IGF-I and IGF-II on proliferation and differentiation of human osteoblasts and interactions with growth hormone. Eur J Clin Invest 28:176-183.

Laurell L, Gottlow J, Zybutz M, Persson R (1998). Treatment of intrabony defects by different surgical procedures. A literature review. $J$ Periodontol 69:303313.

Lee MB (1997). Bone morphogenetic proteins: background and implications for oral reconstruction. A review. $J$ Clin Periodontol 24:355-365.

Lekic P, Sodek J, McCulloch CA (1996). Osteopontin and bone sialoprotein expression in regenerating rat periodontal ligament and alveolar bone. Anat Rec 244:50-58.

Li H, Bartold PM, Zhang CZ, Clarkson RW, Young WG, Waters MJ (1998). Growth hormone and insulin-like growth factor I induce bone morphogenetic proteins 2 and 4: a mediator role in bone and tooth formation? Endocrinology 139:3855-3862.

Liu F, Malaval L, Gupta AK, Aubin JE (1994). Simultaneous detection of multiple bone-related mRNAs and protein expression during osteoblast differentiation: polymerase chain reaction and immunocytochemical studies at the single cell level. Dev Biol 166:220-234.

Liu F, Malaval L, Aubin JE (1997). The mature osteoblasts phenotype is characterised by extensive plasticity. Exp Cell Res 232:97-105.

MacNeil RL, Berry J, D'Errico J, Strayhorn C, Piotrowski B, Somerman MJ (1995). Role of two mineralassociated adhesion molecules, osteopontin and bone sialoprotein, during cementogenesis. Connect Tissue Res 33:1-7.

Matsuda N, Lin WL, Kumar NM, Cho MI, Genco RJ (1992). Mitogenic, chemotactic, and synthetic responses of rat periodontal ligament fibroblastic cells to polypeptide growth factors in vitro. J Periodontol 63:515-25.

Nohutcu RM, McCauley LK, Koh AJ, Somerman MJ (1997). Expression of extracellular matrix proteins in human periodontal ligament cells during mineralization in vitro. J Periodontol 68:320-327.

Parkar MH, Kuru L, O'Hare M, Newman HN, Hughes F, Olsen I (1999). Retroviral transduction of human periodontal cells with a temperature-sensitive SV40 large T antigen. Arch Oral Biol 44:823-834.

Rickard DJ, Kassem M, Hefferan TE, Sarkar G, Spelsberg TC, Riggs BL (1996). Isolation and characterization of osteoblast precursor cells from human bone marrow. $J$ Bone Miner Res 11:312-324.

Shiga T, Shirasawa H, Shimizu K, Dezawa M, Masuda Y, Simizu B (1997). Normal human fibroblasts immortalized by introduction of human papillomavirus type 16 (HPV-16) E6-E7 genes. Microbiol Immunol 41:313-319.

Somerman MJ, Archer SY, Imm GR, Foster RA (1988). A comparative study of human periodontal ligament cells and gingival fibroblasts in vitro. $J$ Dent Res 67:66-70.

Strayhorn CL, Garrett JS, Dunn RL, Benedict JJ, Somerman MJ (1999). Growth factors regulate expression of 
osteoblast-associated genes. J Periodontol 70:13451354.

Tanaka H, Liang CT (1995). Effect of platelet-derived growth factor on DNA synthesis and gene expression in bone marrow stromal cells derived from adult and old rats. J Cell Physiol 164:367-375.

Thesleff I, Nieminen P (1996). Tooth morphogenesis and cell differentiation. Curr Opin Cell Biol 8:844-850.

Thomas T, Gori F, Spelsberg TC, Khosla S, Riggs BL, Conover CA (1999). Response of bipotential human marrow stromal cells to insulin-like growth factors: effect on binding protein production, proliferation, and commitment to osteoblasts and adipocytes. Endocrinology 140:5036-5044. 